Gazi University
Journal of Science
http://dergipark.gov.tr/gujs

\title{
Biodegradation of Low Density Polyethylene by Selected Bacillus sp.
}

\author{
Kartikey KUMAR GUPTA ${ }^{1}$, Deepa DEVI ${ }^{1 *}$ \\ ${ }^{I}$ Gurukul Kangri University, Department of Botany and Microbiology, 249404, Haridwar, Uttarakhand, INDIA.
}

\author{
Highlights \\ - This study focuses on the biodegradation of Low Density Polyethylene by bacterial isolates. \\ - Reduction in weight was estimated by shake flask experiment. \\ - Bacterial biomass on LDPE surface revealed the colonization of bacterial cells. \\ - The polyethylene film was characterized by SEM and FTIR.
}

\begin{tabular}{l} 
Article Info \\
\hline \\
Received: 13/12/2018 \\
Accepted: 13/03/2019 \\
Keywords \\
\hline Low density polyethylene \\
Biodegradation \\
Biofilm \\
Hydrophobicity \\
Bacillus sp.
\end{tabular}

\begin{abstract}
The necessity of environment friendly disposal policies designed for the biodegradation of synthetic plastics is tremendously crucial and need attention in the present scenario, considering the hazardous impact of widely used packaging material such as Low Density Polyethylene (LDPE) on the environment. Our study aims to explore the degradation of LDPE by three strains of Bacillus sp. i.e ISJ51, ISJ55 and ISJ57. The magnitude of biodegradation was evaluated by several techniques comprising weight loss of the polyethylene sample, reduction in bacterial hydrophobicity and estimation of biomass attached to the polyethylene film. The maximum biodegradation i.e., $1.5 \%$, as well as protein content $\left(0.75 \mu \mathrm{g} / \mathrm{cm}^{2}\right)$ of bacterial biofilm adhered on LDPE was observed in Bacillus sp. strain ISJ55 after 60 days of treatment. ISJ55 also demonstrated more hydrophobicity in comparison to ISJ51 and ISJ57, since, a 20.3\% reduction in culture turbidity was specifying better attraction towards hydrophobic substances. SEM analysis revealed that ISJ55 exhibited morphological changes in polyethylene surface while FTIR images showed functional changes after an incubation of 60 days. The establishment of biofilms on polyethylene surface and adhesion capabilities of bacteria are deliberated as the first step in the process of biodegradation. Therefore these results show that the isolate ISJ55 can colonize, modify and utilize LDPE as a sole carbon source, signifying the potential of Bacillus sp. to degrade LDPE film. This manuscript also paves the way for future studies on biodegradation to resolve the universal issue.
\end{abstract}

\section{INTRODUCTION}

Approximately 335 million tonnes of synthetic polymers are being produced in the world every year, out of which, India alone yields approximately 12 million tonnes. Most often used plastics can be classified as polyethylene, polypropylene, polyvinyl chloride etc. Low density Polyethylene (LDPE) are the monomers of ethylene and are generally considered as non-biodegradable in nature owing its higher molecular weight, hydrophobic backbone and chemical formula that implicates solid $\mathrm{C}-\mathrm{C}$ and $\mathrm{C}-\mathrm{H}$ bonds. Apart from that, the three dimensional structure and absence of certain functional groups, also provide extreme resistance to microbial attack. Out of the 15342.6 tonnes of plastic waste generated in India per day, 6137 tonnes remains littered in the environment [1] and accumulates in landfills and natural territories in huge amount [2]. The plastic debris accumulating in the biosphere, cause its harmful effect on all major types of biomes. All kinds of terrestrial ecosystems are being affected by the pollution of polyethylene such as deserts [3], forest, grassland and Polar Regions [4]. Polyethylene and plastics wastes have shown deleterious effect on aquatic environment also as evident by a reduction in marine fauna population, for example, approximately 
267 marine species have been observed to be suffering that included $86 \%$ of sea turtle, $44 \%$ seabird, and $43 \%$ of marine mammal species [5].

The natural degradation of LDPE in the environment is a time consuming procedure, subjected to a number of various environmental factor including temperature, air humidity, moisture content, $\mathrm{pH}$, solar energy, polymer properties and biochemical factors followed by physiological and biochemical nature of microorganisms [6]. Biodegradation is the ability of microbes which influence the degradation of synthetic polymers by secreting extracellular enzymes. Several studies have revealed oxidation of polyethylene by naturally occurring microbes which facilitate the assimilation of polymers by oxidizing it into smaller byproducts such as carbon dioxide and water as their energy source [6-11]. The biodegradation of plastic materials mainly depends upon its hydrophobicity and the size of the polymer molecules. The hydrophobicity of bacterial cell obstructs the colonization of bacterial cell towards the polyethylene surface $[12,13]$.

In earlier studies over 90 genera of fungi and bacteria are reported. Some of the important bacteria reported for the biodegradation of LDPE includes Bacillus spp., Pseudomonas spp., Streptomyces spp., Rhodococcus sp., Acinetobacter sp., Brevibacillus sp., Flavobacterium spp., Ralstonia spp., Staphylococcus spp., Stenotrophomonas spp., Micrococcus spp., Microbacterium sp. and Nocardia sp. Microorganisms have been isolated from various sources having the ability to degrade polyethylene waste [12,14-17]. There is a rising awareness in polymer biodegradation though the use of effective microorganisms. However, successful biodegradation of polyethylene with bacteria has not been achieved till today inspite of best efforts [18]. The diverse physicochemical and biological nature of solid waste indicates that screening of microorganisms from waste disposal sites has got a profound scope in finding more bacterial strains with potential of LDPE degradation $[19,20]$. Therefore assessment of microorganisms to get compatible strains having potential for polyethylene degradation is an essential step. The goal of this research work is to evaluate the capability of bacterial strains for the degradation of synthetic plastics, which is in continuation of our earlier work [21], where we isolated three Bacillus strains from the plastic adhered soil. In this research, we have studied the biodegradation of LDPE by selected Bacillus sp. through the weight loss laboratory scale experiment in contrast to measuring their hydrophobicity and bacterial biomass formed on polyethylene surface.

\section{MATERIAL AND METHODS}

\subsection{Isolation and Screening of Bacterial Isolates}

Polyethylene degrading Bacillus sp. were isolated from plastic adhered soil by clear zone method in our previous study and designated as ISJ 51, ISJ55 and ISJ57 [21]. The cultures were maintained on nutrient agar and nutrient broth for further biodegradation studies.

\subsection{Sterilization of Polyethylene Film}

LDPE sheets used in this work were collected from VSPN Packaging industries, Bhagwanpur, (Haridwar) India. For the biodegradation studies, LDPE films were cut into pieces $(3 \times 3 \mathrm{~cm}$ each $)$ and immersed to a mixture, having $18 \mathrm{ml}$ tween $80,10 \mathrm{ml}$ bleach and $78 \mathrm{ml}$ distilled water for $2-3$ hours. After that polyethylene samples were sterilized in ethanol. They were aseptically relocated to a $70 \% \mathrm{v} / \mathrm{v}$ solution of ethanol for half an hour. Finally, polyethylene pieces were dried overnight at $45^{\circ}-50^{\circ} \mathrm{C}$ and weighted. Ethanol was used as a disinfectant to remove any impurities attached to its surface [22].

\subsection{Hydrophobicity of Bacterial Isolates}

The hydrophobicity of bacterial cell was assessed by bacterial adhesion to hydrocarbon (BATH) test with some modification [23]. For this test fresh cultures of bacteria were prepared in nutrient broth medium until the mid-logarithmic phase. Then centrifugation was done followed by washing with PUM buffer having 17 $\mathrm{g} / 1 \mathrm{~K}_{2} \mathrm{HPO}_{4}, 7.26 \mathrm{~g} / 1 \mathrm{KH}_{2} \mathrm{PO}_{4}, 1.8 \mathrm{~g} / \mathrm{l}$ urea, and $0.2 \mathrm{~g} / 1 \mathrm{MgSO}_{4} \cdot 7 \mathrm{H}_{2} \mathrm{O}$. After washing bacterial cells were re- 
suspended in PUM buffer attending an optical density value of 1.0 to 1.2 at $600 \mathrm{~nm}$. Around $1.2 \mathrm{~mL}$ of this bacterial suspension was transferred to a set of test tubes. Increasing volumes (range 0 to $0.2 \mathrm{ml}$ ) of hexadecane were added to the tubes to check the interaction between bacteria and hydrocarbons. The tubes were allowed to stand for $2 \mathrm{~min}$ for the transfer of bacterial cell which facilitate phase separation. The $\mathrm{OD}_{600}$ was measured for the aqueous suspension. Cell-free buffer served as the blank

$$
\% \text { Hydrophobicity }=\frac{O . D \text { of initial bacterial suspension }-O . D \text { of aqueous phase }}{O . D \text { of initial bacterial suspension }} \times 100 \text {. }
$$

\subsection{Estimation of Viability of Bacterial Isolates}

The growth and viability of bacterial cells was tested by calculating $\mathrm{CFU} / \mathrm{cm}^{2}$ of the microorganism attached to the LDPE surface as biofilm with slight modifications [24]. For this, $5 \mathrm{ml}$ of 24 hour old culture (ISJ51, ISJ55 and ISJ57) grown in nutrient agar medium was inoculated into a flask holding $100 \mathrm{ml}$ of Bushnell Haas Broth Medium (BHM) containing (per liter of distilled water): $0.2 \mathrm{~g} \mathrm{MgSO}_{4}, 0.02 \mathrm{~g} \mathrm{CaCl}_{2}$, $1.0 \mathrm{~g} \mathrm{KH}_{2} \mathrm{PO}_{4}, 1.0 \mathrm{~g} \mathrm{~K}_{2} \mathrm{HPO}_{4}, 1.0 \mathrm{~g} \mathrm{NH}_{4} \mathrm{NO}_{3}, 0.05 \mathrm{~g} \mathrm{FeCl}_{2}$, and $0.1 \mathrm{~g}$ of $(3 \times 3 \mathrm{~cm}) \mathrm{LDPE}$ films as a sole carbon source. The flasks were incubated for a period of 60 days in a rotatory shaker at $180 \mathrm{rpm}$ and $37^{\circ} \mathrm{C}$. The viability of bacterial cells attached on polyethylene films were checked by removing the LDPE sheets from the flask after every 20 days of interval. The bacterial biomass stick to the polyethylene surface was scratched and suspended in $0.85 \%$ saline and serially diluted. The viable cells were detected on nutrient agar medium in the form of colony forming unit.

\subsection{Estimation of Bacterial Biomass}

The biomass adhered to the LDPE film was estimated in the form of total protein content. The pieces of polyethylene films were recovered from the medium after an interval of every 20 days and washed gently with water to remove any medium debris. The surface-adhered bacterial cells were detached from the film by a mild water bath sonication in $1 \mathrm{ml}$ of $0.85 \%$ of saline for $4 \mathrm{~min}$. The saline solution obtained, was subjected to calculate the protein concentration [25]. A separate setup was prepared for each isolate containing 3 flask in triplicates for every 20,40 and $60^{\text {th }}$ days incubation period with pre- weighed polyethylene. The concentration of total protein content in the extract was determined spectrophotometrically at $595 \mathrm{~nm}$ by using Bradford assay [25, 26]. For this assay, a series of protein standards (dilutions of a protein solution of known concentration) were prepared and the absorbance was plotted against known protein concentration. Then the absorbance of test sample was measured. The amount of protein can be determine by using the standard curve.

\subsection{Shake Flask Experiment for Bacterial Isolates}

The shake flask assay was executed on laboratory scale to determine the degradation of LDPE film by bacterial isolates. The pieces of polyethylene bags (approximately $100 \mathrm{mg}$ of polyethylene film per flask) were supplemented with $100 \mathrm{ml}$ of bushnell haas broth medium (BHM). The flasks were inoculated with 5 $\mathrm{ml}$ of 24 hour old culture of ISJ51, ISJ55 and ISJ57 respectively. Then the flasks were incubated in a shaker at $35^{\circ} \mathrm{C}$ at $180 \mathrm{rpm}$ for 60 days. Un-inoculated BHM contains polyethylene as a substrate used as control.

\subsection{Determination of Dry Weight of LDPE Film}

The weight of LDPE films was calculated in the form of percent (\%) biodegradation, residual LDPE sheets were sampled from the culture medium and washed with a solution of $2 \%(\mathrm{v} / \mathrm{v})$ sodium dodecyl sulfate( SDS) for 2-3 hours. For the elimination of any kind of impurity and organic matter the films were rinsed thoroughly with distilled water [12]. The washed and cleaned LDPE films were dried overnight at $60^{\circ} \mathrm{C}$. After that the weight loss of residual polyethylene was calculated by using the formula [27]:

$$
\% \text { Biodegradation }=\frac{\text { Initial weight }- \text { Final weight }}{\text { Initial weight }} \times 100 .
$$




\subsection{Surface Analysis}

\subsubsection{Scanning Electron Microscopy}

The polyethylene films were subjected to SEM analysis after the completion of incubation period. For this analysis untreated and treated polyethylene samples were washed with $2 \%(\mathrm{v} / \mathrm{v})$ aqueous SDS and distilled water for few minutes. Additionally the samples were washed with $70 \%$ ethanol to remove any surface attached cells. Then the samples were pasted onto the Sample Stub with the help of a carbon tape. After stubbing the samples were coated with gold for $40 \mathrm{~s}$ and observed under scanning electron microscope to detect any changes in polyethylene surface.

\subsubsection{FTIR Analysis}

The functional changes in the polyethylene films were detected through Fourier transform infrared spectroscopy. Both the polyethylene samples i.e, incubated with the bacteria and control were analyzed by FTIR spectroscopy after an incubation period of 60 days. The polyethylene samples were analyzed to monitor any formation and disappearance of functional groups through FTIR spectra in the frequency range of $4000-400 \mathrm{~cm}^{-1}$.

\section{STATISTICAL ANALYSIS}

All experiments were performed in triplicates and standard error mean was calculated for each experiment by using MS Office excel program. The bacterial growth and viability on polyethylene surface were analyzed by ANOVA $(\mathrm{P}<0.01)$.

\section{RESULTS AND DISCUSSION}

The bacterial isolates used in present work were previously isolated from partially degraded polyethylene samples in our earlier studies. The three bacterial isolates namely ISJ51, ISJ55 and ISJ57 were selected for degradation studies on the basis of clear zone formation. As colonization of microbes on polymer surface considered as the primary step for biodegradation, therefore in this research work Bacillus strains were grown in a LDPE supplemented synthetic medium to evaluate the colonization ability or hydrophobicity of the bacteria towards hydrophobic surface [28].

\subsection{Determination of Cell Surface Hydrophobicity}

Due to hydrophobic nature of LDPE surface, it has generally been considered that better interaction of bacteria with polyethylene will take place only when hydrophobicity of bacterial cell surface is on higher side [12]. In this study the interface between bacteria cell and polyethylene surface was ascertain by BATH test by quantifying the cell surface hydrophobicity of bacterial strains to hydrocarbon and the \% hydrophobicity of the isolates are displayed in Figure 1. The bacterial isolates seems to be hydrophobic even at a very low concentration of hexadecane, resulting in an approximately $12.11 \%, 20.3 \%$ and $11.28 \%$ reduction in the turbidity for ISJ51, ISJ55 and ISJ57 respectively. At a minimum concentration of hexadecane $(0.2 \mathrm{ml})$ ISJ55 showed a maximum reduction in turbidity $(20.3 \%)$. As well as previous study revealed a reduction in turbidity (20\%) for Rhodococcus ruber upon exposure to hexadecane [13]. In an earlier study, two marine bacteria namely, Kocuria palustris and Bacillus subtilis has been reported a significant escalation (32\%) in the hydrophobicity [18]. The hydrophobicity of polyethylene hinders the development of biofilm by bacteria which in return prevents the attachment of bacteria towards polyethylene surface $[29,30]$. The BATH assay for the assessment of bacterial cell surface hydrophobicity is depend on the affinity of microorganism for a hydrocarbon such as hexadecane. In this test a significant increase in bacterial hydrophobicity was caused by transfer of bacterial cell from the aqueous phase to hexadecane. The main reason behind this transfer is that the bacteria tend to possess greater affinity for the hydrocarbons if they are more hydrophobic. 


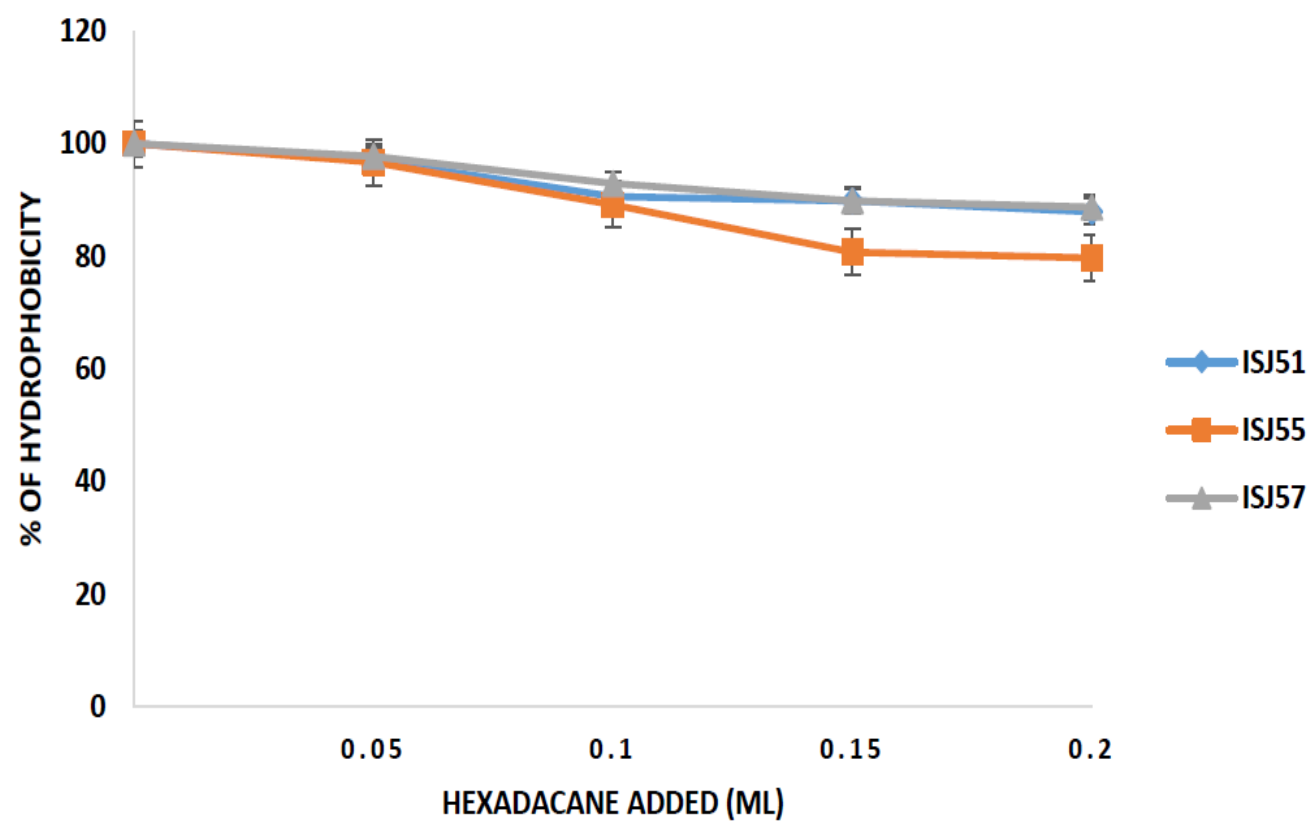

Figure 1. The hydrophobicity of bacterial isolates ISJ51, ISJ55 and ISJ57 were determined spectrophotometrically by BATH test an optical density at $600 \mathrm{~nm}$. A decrease in the turbidity of the bacterial suspension was observed due to the transfer of bacterial cells from aqueous phase to hexadecane. The experiment was performed in triplicates and the bars are showing standard error mean ( \pm SEM)

\subsection{Bacterial Cell Growth on Polyethylene Surface}

Figure 2 displayed the growth rate of bacterial strains in liquid medium in the presence of polyethylene film. Bacillus sp. ISJ55 exhibited significant growth upon exposure to LDPE films. An exponential increase in the growth from day 20 to day 60 was observed in all three isolates, however, highest growth was exhibited by ISJ55 $\left(1.3 \times 10^{9} \mathrm{CFU} / \mathrm{cm}^{2}\right)$ followed by ISJ51 $\left(1.1 \times 10^{9} \mathrm{CFU} / \mathrm{cm}^{2}\right)$ and ISJ57 $\left(9.5 \times 10^{8}\right.$ $\left.\mathrm{CFU} / \mathrm{cm}^{2}\right)$. Nevertheless, a rise in bacterial population after the $60^{\text {th }}$ day of incubation does not suggest the better performance of the isolate, however, a significant increase in bacterial cell counts may allow favorable interaction between the bacterial cell membrane and polyethylene films [31].The existing growth of microbes was probably due to the utilization of polyethylene by all isolates resulting in increasing microbial biomass, which could have resulted in the biodegradation of the polyethylene film [32]. However Walczak et al. 2015 [33] reported that "the abundance of biofilm formed on polyethylene surface by specific bacterial strains does not always correlate with their hydrolytic activity, which is important in the context of biodegradation." Our results supports the theory and indicated that the differences in response to polyethylene could indicate the variations that exist in metabolic rate, polymer uptake mechanism, and associated genetic alteration within the individual isolates (ISJ 51 and ISJ57). 


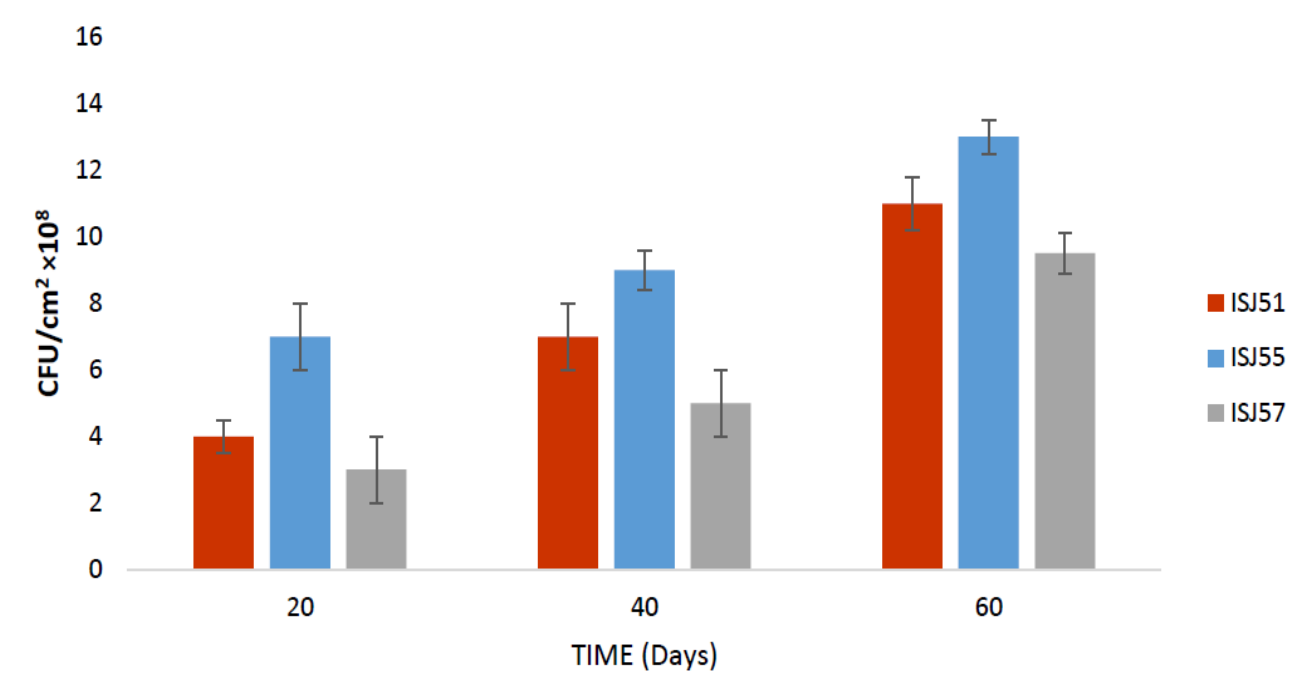

Figure 2. Viable cell counts of bacterial strains $\left(C F U / \mathrm{cm}^{2}\right)$ on LDPE surface. The bars showed standard error mean $( \pm$ SEM). Statistical significance was calculated by one way Anova at $p<0.01$ significance level.

These results implied that both the isolates were able to maintain their metabolic activity in the polyethylene supplemented medium but does not suggest any detectable changes in polyethylene weight. The variations in the metabolic rates within bacterial species were possibly accountable for different responses exhibited by the isolates. Generally, ISJ55 exhibited more tolerance between the 20th and the 60th days of exposure to the polyethylene film than ISJ51 and ISJ57. This highest growth rate of ISJ55 towards polyethylene exposure was probably due to the potential of ISJ55 which significantly influence the bonds of the polyethylene film as indicated in FTIR spectra. This outcome illustrated that the microbes were adjusted to the starvation conditions of the polyethylene culture media and was probably utilizing LDPE as a carbon source for their growth. The growth pattern of the isolates was significantly differed $(\mathrm{P}<0.01)$ during the different days of incubation.

\subsection{Quantification of Protein Content}

The growth kinetics of the development of biofilm formation on the LDPE surface was enumerated by extracted proteins. The values illustrated in Figure 3, indicates a pattern of biofilm establishment on the polyethylene surface, which ensures that an escalation in protein content from the first 20 days of incubation, reflecting an increase in the bacterial biomass at the completion of the incubation period. The extractable proteins attached to the LDPE surface was higher in the case of ISJ 55 cultures than that of the other two isolates i.e. ISJ51 and ISJ57. A regular growth of bacterial strains on polyethylene film suggests continuous increase in extractable proteins, consequently the biomass on polyethylene surface is continuously proliferating. This result agrees with viable cell count of bacteria, which was measured in the form of CFU. Similar results were found by Aravinthan 2016, [34] when they treated polypropylene (PP) with B. flexus and B. subtilis for a period of 12 months. 


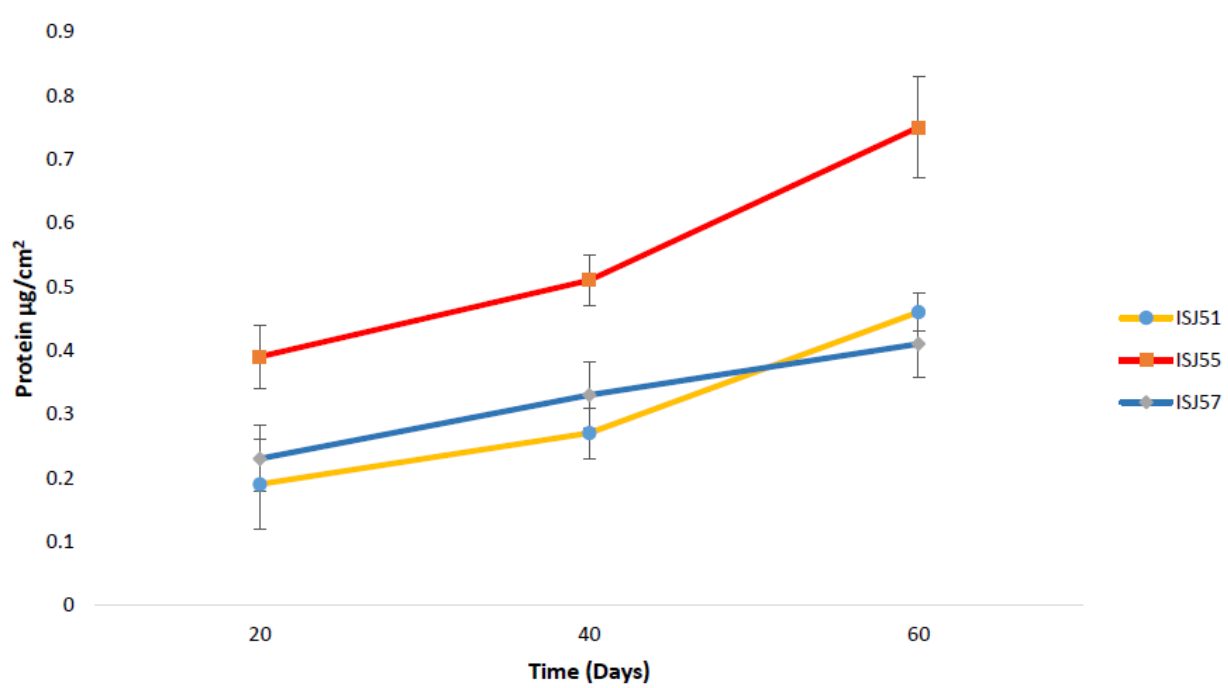

Figure 3. Protein contents of bacterial cultures (ISJ51, ISJ55, ISJ57) in Bushnell hass broth medium supplemented with Polyethylene films. Values represents the mean of three independent experiment. Bars indicated standard error mean ( \pm SEM)

\subsection{Biodegradation of Plastic}

The biodegradation of polyethylene was quantitatively assessed by performing a laboratory scale shake flask experiment under controlled conditions. The percent reduction in polyethylene film was presented in Figure 4 . The reduction in weight of LDPE was $1.5 \pm .05 \%$ after 60 days of biodegradation assessment with ISJ55. Whereas ISJ51 and ISJ57 were unable to show any detectable changes in polyethylene films in term of weight loss. While no weight loss was observed in un-inoculated flask. Our results suggest more valuable degradation of LDPE in comparison with a previous study conducting by Aravinthan et al. (2016) [34] resulting into $1.48 \pm 0.11 \%$ weight loss of polypropylene after an incubation of 12 months inoculated with B. flexus and B. subtilis . On the other hand Harshvardhan and Jha [18] reported $1 \pm 0.033 \%, 1.5 \pm 0.038 \%$ and $1.75 \pm 0.06 \%$ weight loss of LDPE for $K$. palustris M16, B. pumilis M27 and B. subtilis H1584 respectevely. Auta et al. 2017 [31] recorded weight loss of 1.6\% for polyethylene by Bacillus cereus.

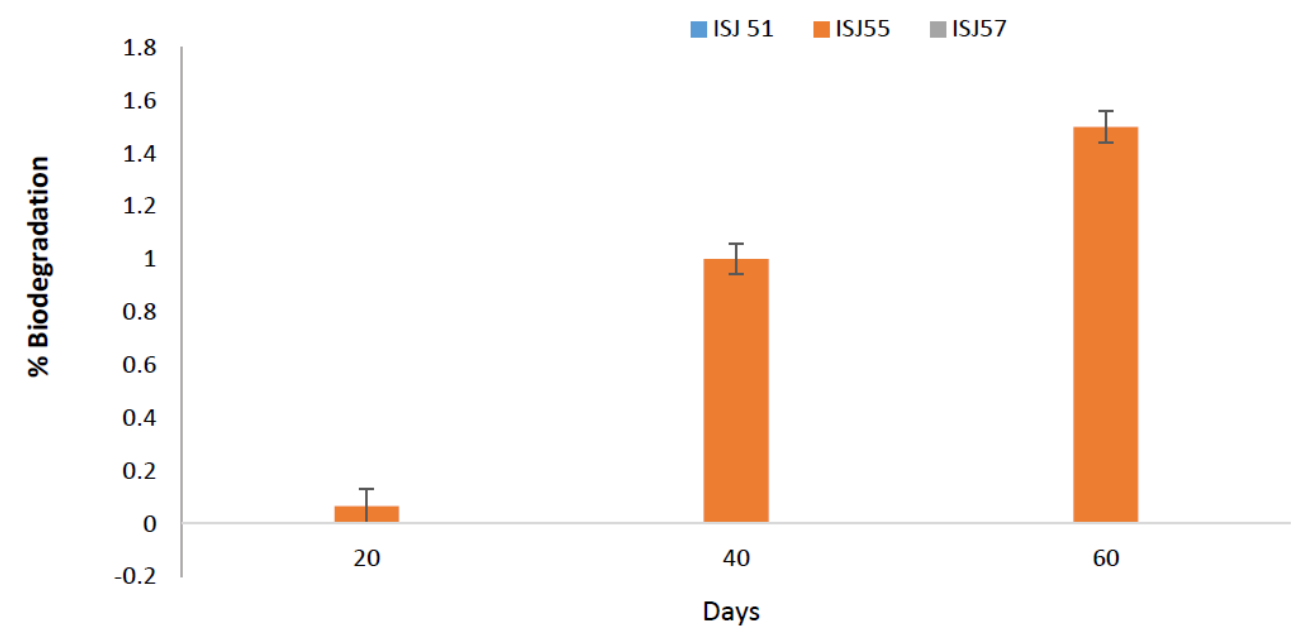

Figure 4. The graph indicates the gradual increase in weight loss of LDPE film with Bacillus sp with the incubation time. The data represents average value of triplicates. Bars showing the standard error mean

The observed weight loss in polyethylene film was a result of microbial action on surface of LDPE film after inoculation with Bacillus sp. The degradation differs from one microbe to another because different microbes contains different characteristics [35]. In previous study it was conclude that the degradation of polyethylene resulting in the physical breakdown and loss of certain properties and functional groups of 
polyethylene [36] which is due to the capability of microbes to secrete extracellular enzymes that can attack on LDPE. The breakdown and weight loss of LDPE film was possibly due to the catalyzation of metabolic reactions by the isolates. To confirm the biodegradation, polyethylene samples treated with ISJ55 were subjected to SEM and FTIR analysis.

\subsection{Scanning Electron Microscopy}

The extent of biodegradation was examined by detecting the changes in surface morphology through SEM analysis. Several changes were observed in physical appearance of LDPE film treated with ISJ55 after 60 days incubation. However the untreated polyethylene sample displayed a smooth surface (Figure 5A). The microbially treated sample confirms surface distortion by exhibiting various cracks and irregularities formed as a result of microbial activity (Figure 5B). The exhibited alteration in the surface of polyethylene films observed in the SEM micrographs indicates that the surface damage is due to Bacillus sp. These outcomes suggested that our isolate was able to use LDPE film as a sole carbon source and cause surface erosion, consequently, weight loss in LDPE sample takes place. This phenomenon supports a number of earlier studies reported similar morphological changes on LDPE surface by the action of microorganism $[18,22,27,37]$.
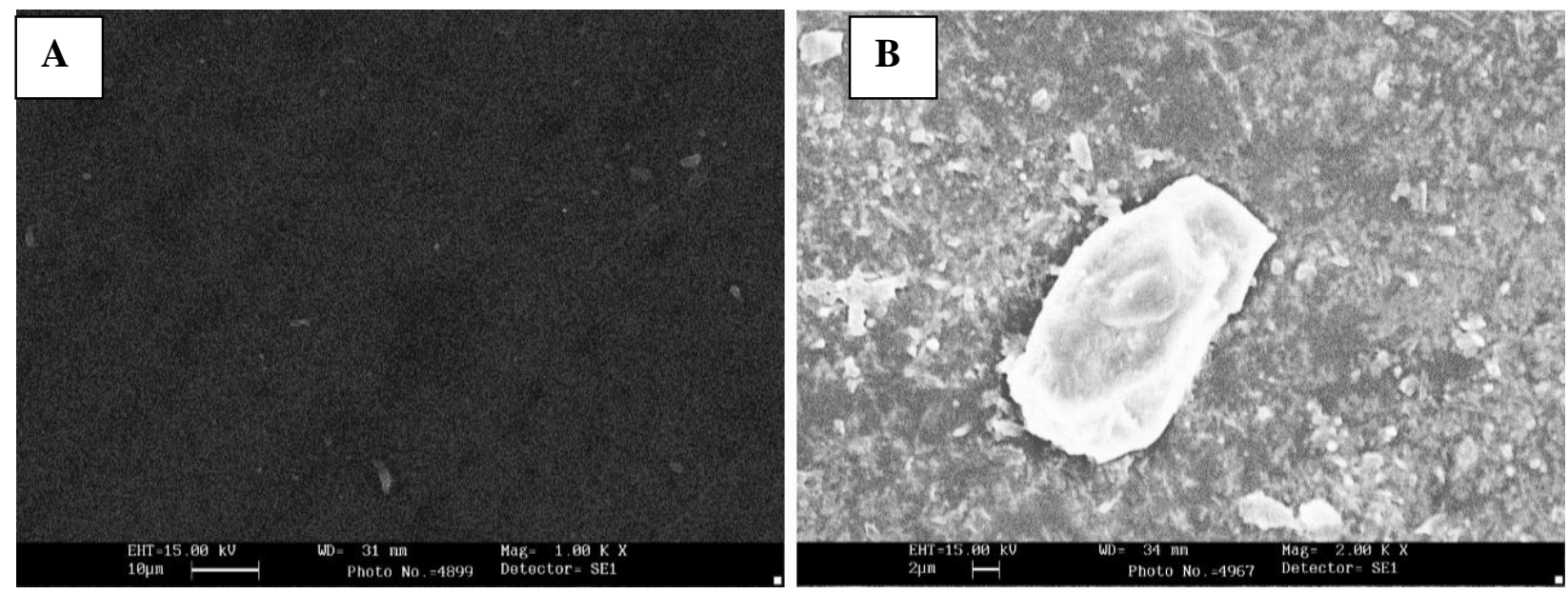

Figure 5. SEM micrographs of Polyethylene film (A) un-inoculated (control) LDPE (B) LDPE inoculated with Bacillus sp.ISJ55

\subsection{FTIR}

In the process of biodegradation of polyethylene, microorganism secretes extracellular enzymes which facilitate a number of chemical reactions that may leads to alteration in chemical conversions including oxidation, reduction, oxidation, esterification, hydrolysis and inner molecular conversion. FTIR is a common tool to detect such types of conversion. The control (un-inoculated polyethylene) sample manifest the complex nature of the polymer (Figure 6A). This technique was used for the detection of any kind of alteration in functional groups comprising the formation and disappearance of $\mathrm{C}-\mathrm{H}$ bond (3442 and 3361 $\left.\mathrm{cm}^{-1}\right)$, ketones $\left(1714 \mathrm{~cm}^{-1}\right)$, double bonds (1608) and vinyl bond $\left(813 \mathrm{~cm}^{-1}\right)$. FT-IR spectra clearly shown the changes in chemical structure, side chain modifications in almost all peaks which confirms the biodegradation of polyethylene film due to microbial activities. When the test samples (inoculated with bacteria) were analyzed, the band intensities of different regions was altered due to the action of bacteria (Figure 6 B). 

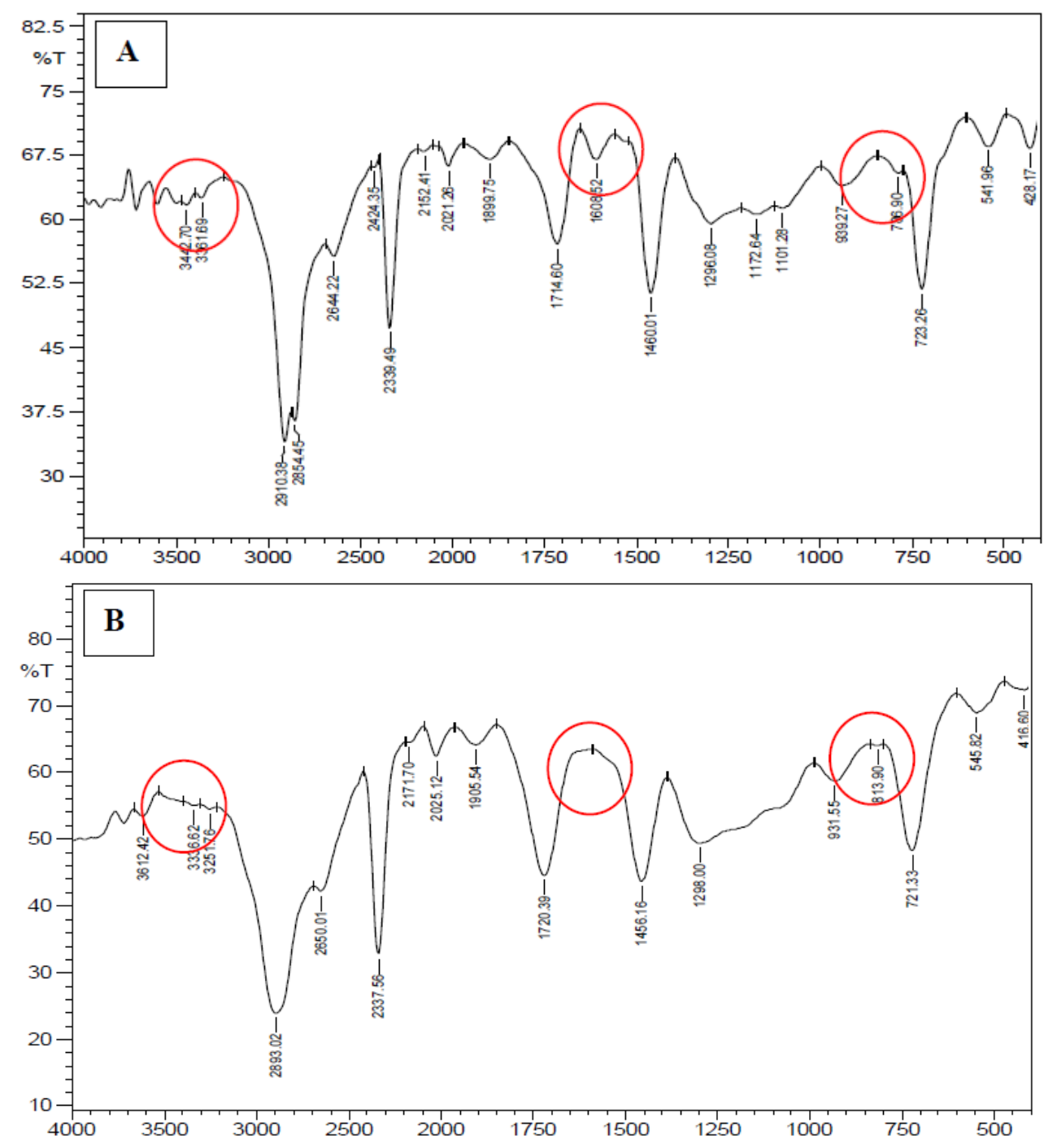

Figure 6. Fourier transform infrared spectra of untreated (control) low-density polyethylene (LDPE) (A) and polyethylene after 60 days of incubation with Bacillus sp. ISJ55 (B)

Our study proves that the biotic environment supports the formation of terminal double bonds (IR 905-915 $\mathrm{cm}^{-1}$ ), the same results were obtained in a previous study when the polyethylene was incubated with bacterial strain. This is due to the Norrish type II reaction which takes place in the formation of double bonds [6]. In earlier research, UV treated polyethylene films were used for biodegradation [12, 17]. In the present work, we used non-UV treated polyethylene for biodegradation studies. FTIR analysis confirms the fact that ISJ55 can modify the chemical nature of polyethylene and cause alteration in functional groups.

\section{CONCLUSION}

It was known that LDPE is resilient to biodegradation. Nevertheless, the present work shows the utilization of LDPE by bacterial strains as carbon source and indicates that microbes are familiarizing towards hydrocarbons. The relatively significant degradation ability of our isolate anticipated that microbes were forced to consume LDPE as the only carbon source. The development of biofilm on LDPE surface was viable and a high bacterial biomass on polyethylene surface reinforces this fact. The reduction in weight of LDPE using Bacillus sp. (ISJ55) was gradually observed as $1.5 \%$ after 60 days of incubation. The formation of new functional groups and reduction in the absorption characteristics of the peaks detected by FTIR spectra with subsequent changes in the morphology of polyethylene surface observed through SEM 
analysis indicates the process of biodegradation. Hence the facts attained as an evidence for degradation of LDPE by Bacillus sp. therefore further studies on molecular level can be done by using these microorganisms to obtain better biodegradation.

\section{CONFLICTS OF INTEREST}

No conflict of interest was declared by the authors.

\section{REFERENCES}

[1] Grover, A., Gupta, A., Chandra, S., Kumari, A., Khurana, S.P., "Polythene and environment", Int. Jour. of Environ. Sci., 5(6): 1091-1105, (2015).

[2] Thompson, R.C., Swan, S.H., Moore, C.J., Vom Saal, F.S., "Our plastic age", Philos. Trans. R. Soc. Lond., B, Biol. Sci., 364(1526): 1973-1976, (2009).

[3] Zylstra, E.R., "Accumulation of wind-dispersed trash in desert environments", J. Arid. Environ., 89: 13-15, (2013).

[4] Gregory, M.R., "Environmental implications of plastic debris in marine settings - entanglement, ingestion, smothering, hangers-on, hitch-hiking and alien invasions", Philos. Trans. R. Soc. Lond., B, Biol. Sci., 364(1526): 2013-2025, (2009).

[5] Browne, M.A., Crump, P., Niven, S.J., Teuten, E., Tonkin, A., Galloway, T., Thompson, R., "Accumulation of microplastic on shorelines woldwide: sources and sinks", Environ. Sci. Technol., 45(21): 9175-9179, (2011).

[6] Albertsson, A.-C., Andersson, S.O., "The mechanism of biodegradation of polyethylene", Polym. Degrad. Stab., 18(1): 73-87, (1987).

[7] Albertsson, A.-C., Erlandsson, B., Hakkarainen, M., Karlsson, S.,"Molecular weight changes and polymeric matrix changes correlated with the formation of degradation products in biodegraded polyethylene", J. Environ. Polym. Degrad., 6(4): 187-195, (1998).

[8] Albertsson, A.-C., Erlandsson, B., Hakkarainen, M., Karlsson, S.,"Molecular weight changes and polymeric matrix changes correlated with the formation of degradation products in biodegraded polyethylene", J. Environ. Polym. Degrad., 64: 91-99, (1999).

[9] Lee, B., Pometto, A.L., Fratzke, A., Bailey, T.B., "Biodegradation of degradable plastic polyethylene by Phanerochaete and Streptomyces Species", Appl. Environ. Microbiol., 57(3): 678-685, (1991).

[10] Erlandsson, B., Karlsson, S., Albertsson, A.-C., "The mode of action of corn starch and a pro-oxidant system in LDPE: influence of thermo-oxidation and UV-irradiation on the molecular weight changes", Polym. Degrad. Stab., 55(2): 237-245, (1997).

[11] Chiellini, E., Corti, A., Swift, G., "Biodegradation of thermally-oxidized, fragmented low-density polyethylenes", Polym. Degrad. Stab., 81(2): 341-351, (2003).

[12] Orr, I.G., Hadar, Y., Sivan, A., "Colonization, biofilm formation and biodegradation of polyethylene by a strain of Rhodococcus ruber", Appl. Microbiol. Biotechnol., 65(1): 97-104, (2004). 
[13] Sivan, A., Szanto, M., Pavlov, V., "Biofilm development of the polyethylene-degrading bacterium Rhodococcus ruber", Appl. Microbiol. Biotechnol., 72(2): 346-352, (2006).

[14] Kathiresan, K., "Polythene and plastics-degrading microbes from the mangrove soil", Rev. Biol. Trop., 51(3): 629-633, (2003).

[15] Pramila, R., Ramesh, K.V., "Biodegradation of low density polyethylene (LDPE) by fungi isolated from marine water a SEM analysis", Afr. J. Microbiol. Res., 5(28): 5013-5018, (2011).

[16] Pramila, R., Ramesh, K.V., "Biodegradation of low density polyethylene (LDPE) by fungi isolated from municipal landfill area", Journal of Microbiology and Biotechnology Research, 1(4): 131-136, (2017).

[17] Hadad, D., Geresh, S., Sivan, A., "Biodegradation of polyethylene by the thermophilic bacterium Brevibacillus borstelensis", J. Appl. Microbiol., 98(5): 1093-1100, (2005).

[18] Harshvardhan, K., Jha, B., "Biodegradation of low-density polyethylene by marine bacteria from pelagic waters, Arabian Sea, India", Mar. Pollut. Bull., 77(1-2): 100-106, (2013)

[19] Restrepo-Flórez, J.-M., Bassi, A., Thompson, M.R., "Microbial degradation and deterioration of polyethylene-A review", Int. Biodeterior. Biodegrad., 88: 83-90, (2014).

[20] Atalia, K.R., Buha, D.M., Joshi, J.J., Shah, N.K., "Microbial biodiversity of municipal solid waste of Ahmedabad", J. Mat. Environ. Sci., 6(7): 1914-1923, (2015).

[21] Gupta, K.K., Devi, D., "Isolation and characterization of low density polyethylene degradıng Bacillus spp. From garbage dump sites", World J. of Pharm. Sci., 6(11): 609-617, (2017).

[22] Awasthi, S., Srivastava, N., Singh, T., Tiwary, D., Mishra, P.K., "Biodegradation of thermally treated low density polyethylene by fungus Rhizopus oryzae NS 5", 3 Biotech., 7(1): 73, (2017).

[23] Rosenberg, M., Gutnick, D., Rosenberg, E., "Adherence of bacteria to hydrocarbons: a simple method for measuring cell-surface hydrophobicity", FEMS. Microbiol. Lett., 9(1): 29-33, (1980).

[24] Sivakumar, P.M., Iyer, G., Natesan, L., Doble, M., "3'-Hydroxy-4-methoxychalcone as a potential antibacterial coating on polymeric biomaterials", Appl. Surf. Sci., 256(20): 6018-6024, (2010).

[25] Arkatkar, A., Juwarkar, A.A., Bhaduri, S., Uppara, P.V., Doble, M., "Growth of Pseudomonas and Bacillus biofilms on pretreated polypropylene surface", Int. Biodeterior. Biodegrad., 64(6): 530-536, (2010).

[26] Bradford, M.M., "A Rapid and Sensitive Method for the Quantitation of Microgram Quantities of Protein Utilizing the Principle of Protein-Dye Binding", Anal. Biochem., 72(1-2): 248-254, (1976).

[27] Kyaw, B.M., Champakalakshmi, R., Sakharkar, M.K., Lim, C.S., Sakharkar, K.R., "Biodegradation of low density polythene (LDPE) by Pseudomonas species", Indian. J. Microbiol., 52(3): 411-419, (2012).

[28] Yabannavar, A., Bartha, R., "Biodegradability of some food packaging materials in soil", Soil. Biol. Biochem., 25(11): 1469-1475, (1993).

[29] Ribitsch, D., Acero, E.H., Greimel, K., Eiteljoerg, I., Trotscha, E., Freddi, G., Schwab, H., Guebitz, G.M., "Characterization of a new cutinase from Thermobifida alba for PET-surface hydrolysis", Biocatal. Biotransformation., 30(1): 2-9, (2012). 
[30] Yoshida, S., Hiraga, K., Takehana, T., Taniguchi, I., Yamaji, H., Maeda, Y., Toyohara, K., Miyamoto, K., Kimura, Y., Oda, K., "A bacterium that degrades and assimilates poly (ethylene terephthalate)", Science., 351(6278): 1196-1199, (2016).

[31] Auta, H.S., Emenike, C.U., Jayanthi, B., Fauziah, S.H., "Growth kinetics and biodeterioration of polypropylene microplastics by Bacillus sp. and Rhodococcus sp. isolated from mangrove sediment", Mar. Pollut. Bull., 127: 15-21, (2018).

[32] Okpokwasili, G.C., Nweke, C.O., "Microbial growth and substrate utilization kinetics", Afr. J. Biotechnol., 5(4): 305-317, (2006).

[33] Walczak, M., Brzezinska, M.S., Sionkowska, A., Michalska, M., Jankiewicz, U., Deja-Sikora, E., "Biofilm formation on the surface of polylactide during its biodegradation in different environments", Colloid. Surface. B., 136: 340-345, (2015).

[34] Aravinthan, A., Arkatkar, A., Juwarkar, A.A., Doble, M., "Synergistic growth of Bacillus and Pseudomonas and its degradation potential on pretreated polypropylene", Prep. Biochem. Biotechnol., 46(2): 109-115, (2016).

[35] Bhardwaj, H., Gupta, R., Tiwari, A., "Microbial population associated with plastic degradation", Sci. Rep., 5: 272-274, (2012).

[36] Board, N., The complete book on biodegradable plastics and polymers (recent developments properties, analyses, materials \& processes), Asia Pacific Business Press, Delhi, (2006).

[37] Das, M.P., Kumar, S., "An approach to low-density polyethylene biodegradation by Bacillus amyloliquefaciens", 3 Biotech., 5(1): 81-86, (2015). 